\title{
FEEDING PREFERENCE FOR SELECTED TILIA SPP. AND CULTIVARS BY THE ADULT JAPANESE BEETLE (COLEOPTERA: SCARABAEIDAE)
}

\author{
by Fredric Miller ${ }^{1}$ and George Ware ${ }^{2}$
}

\begin{abstract}
Species and hybrids of Tilia are widely used in urban landscapes and as street trees. Planting Tilia species that are less preferred by the Japanese beetle (Popillia japonica Newman) would greatly minimize the need for insecticide sprays, which would in turn reduce environmental contamination, human exposure, and management costs. Thus, a study was initiated to evaluate horticulturally desirable Tilia spp. for feeding preference by the adult Japanese beetle. A secondary objective of the study was to determine if leaf pubescence is a factor in feeding preference. The Asian species of $T$. petiolaris, $T$, oliveri, $T$. chinensis, and $T$. japonica show promise for partial resistance to Japanese beetle. Three North American species, T. americana, $T$. heterophylla, and $T$. caroliniana, also look promising along with the pubescent European species of $T$. tomentosa and T, tomentosa 'Erecta'.
\end{abstract}

Key Words. Tilia spp; linden; feeding preference; Japanese beetle; leaf pubescence; host plant resistance.

Since its introduction into the United States around 1916, the Japanese beetle (Popillia japonica Newman) has become one of the most destructive and difficult pests of nursery crops and landscape plants to manage. Adult beetles feed on approximately 300 species of wild and cultivated plants including, but not limited to, members of Rosaceae, Malvaceae, Vitaceae, Polygonoceae, Aceraceae, Ulmaceae, and Salicaceae (Fleming 1972; Ladd 1987; Spicer et al. 1995). Highly preferred hosts include lindens (Tilia spp.), sassafras (Sassafras albidum [Nuttall] Nees), and purple plum (Prunus cerostifera Erhart), which all may be completely defoliated by adult beetles.

Host plant resistance for $P$. japonica is poorly documented (Raupp et al. 1992), with susceptible or resistant plant lists being compiled from anecdotal descriptions and field observations (Hawley and Metzger 1940; Fleming 1972; Spicer et al. 1995). In addition, feeding studies conducted by Ladd (1987, 1989) have revealed considerable variation in feeding preference by $P$ japonica among plant species listed by Fleming (1972) as being either favored hosts, minor hosts, or nonhost species (Spicer et al. 1995).
Information on $P$. japonica feeding preference among cultivars or varieties of common hosts also is limited. Feeding damage ratings for $P$. japonica were conducted by Ranney and Walgenbach (1992) on selected cultivars of birch, cherry, and crabapple during one growing season. In addition, Spicer et al. (1995) studied the resistance of 42 Malus cultivars for defoliation by the Japanese beetle over several growing seasons. More recently, Potter et al. (1998) examined the relative susceptibility of cultivars of flowering crabapples, lindens, and roses for defoliation by adult Japanese beetles.

Because of the widespread use of Tilia spp. in urban landscapes and as street trees, planting Tilia species that are less preferred by the Japanese beetle would greatly minimize the need for insecticidal sprays, which would in turn reduce environmental contamination, human exposure, and management costs. With these goals in mind, a study was initiated to evaluate potential horticulturally desirable Tilia spp. for feeding preference by the adult Japanese beetle and to determine if leaf pubescence is a factor in feeding preference.

\section{MATERIALS AND METHODS No-Choice Laboratory Feeding Tests}

No-choice feeding tests were conducted using fieldcollected adult male and female Japanese beetles during the 1995 and 1997 growing seasons. In 1995, 16 Tilia genotypes, growing in the Tilia collection at The Morton Arboretum (Lisle, Illinois) were evaluated, with Tilia cordata serving as a reference (see Table 1 for a listing of genotypes tested). In 1997, 3 Tilia genotypes (Table 2) also growing in the Tilia collection were tested. Linden species/hybrids and Sassafras albidum (considered a reference) for both studies ranged in height from 8 to $15 \mathrm{~m}$ (26 to $49 \mathrm{ft}$ ), with diameters at breast height ranging from 5 to $50 \mathrm{~cm}$. (2 to $20 \mathrm{in}$.). Also in 1997, 7 additional Tilia genotypes growing in 3.8-L (10-gal.) paper pots 
in The Morton Arboretum tree nursery, $2.5 \mathrm{~cm}$ ( $1 \mathrm{in}$.) in diameter, and approximately $2 \mathrm{~m}(6 \mathrm{ft})$ tall were tested for feeding preference (refer to Table 3 for a listing of genotypes tested). The selection of Tilia genotypes for all feeding tests was based on their horticultural qualities and potential use in landscapes and urban forests. The number of individual trees tested in each study was based on availability, with 1 to 5 trees randomly selected within a given Tilia genotype.

Leaves were collected randomly from the lower half of the trees at all 4 cardinal directions. The leaf samples included the terminal $31 \mathrm{~cm}$ (12 in.) of linden branches. Samples consisted of an equal proportion of actively growing and senescent foliage for each tree. Only fully expanded leaves were used. Leaf samples were taken in this way to compensate for leaf quality within trees. Leaf samples were held in cold storage in plastic bags for a maximum of 2 days. Leaves from each test tree were combined for the trials. Depending on availability, 1 tree (1995) to 5 trees (1997) of each species/hybrid were randomly selected and evaluated. With the exception of the lindens growing in the paper pots (1997 test), all lindens were growing close to each other in the Tilia collection at The Morton Arboretum.

Adult beetles used in the no-choice studies were field collected at The Morton Arboretum and at the Chicago Botanic Garden (Glencoe, Illinois). Upon arrival at the laboratory, beetles were placed in clear plastic cages along with fresh crabapple foliage and held under a photoperiod of 16:8 (L:D) hours at approximately $25^{\circ} \mathrm{C}\left(77^{\circ} \mathrm{F}\right)$.

For the 1995 test, 2 unsexed beetles were placed in each of 10 replicate plastic petri dishes, $(0.6 \times$ $10 \mathrm{~cm}[0.2 \times 4 \mathrm{in}]$.$) with foliage from the test linden$ species/hybrids. Petri dishes were examined daily for evidence of feeding and beetle mortality. Foliage was replaced every 2 days. Beetles that died within the first 3 days were replaced to ensure that healthy beetles had an opportunity to feed on test lindens. The petri dishes were placed in clear plastic bags to prevent drying of the foliage and were held under a 16 -hour photoperiod at approximately $25^{\circ} \mathrm{C}\left(77^{\circ} \mathrm{F}\right)$. Condensation of water on the lid of the petri dishes indicated a high relative humidity. One tree of every species/hybrid was tested. After 1 week, the foliage was removed from the dishes, marked with a perma- nent marker as to genotype and dish number, placed in a plant press, and dried in a herbarium drying oven. After drying, leaf area (nearest $\mathrm{mm}^{2}$ ) was measured using a Licor meter, after which the remaining leaf area after feeding was measured. The measure of acceptance of each genotype was defined by the mean percent leaf area consumed and mean dried fecal pellet weight. Leaf area consumed was calculated by subtracting leaf area remaining after feeding from initial leaf area before feeding and then dividing this value by the initial leaf area before feeding to obtain a percentage of leaf area consumed. Fecal pellets were removed from each dish, labeled, dried, and then weighed (nearest $0.1 \mathrm{mg}$ ). The measure of acceptance of each genotype was defined by the mean percent leaf area consumed and mean dried fecal pellet weight.

In 1997, no-choice laboratory tests were performed as described previously except that only 1 unsexed adult Japanese beetle was placed in the petri dish with the candidate foliage. Because of the laborious task of preparing foliage for leaf area measurements, visual estimates of percent defoliation (nearest 10\%) were used. All other methods are as described previously.

\section{Multiple-Choice Laboratory Feeding Study, 1997}

One unsexed adult Japanese beetle was placed in each of 10 replicate plastic petri dishes $(0.6 \times 15 \mathrm{~cm}$ [0.2 25.9 in.]). Six circular leaf discs, $2.5 \mathrm{~cm}$ (1 in.) in diameter, each representing 6 different linden genotype choices, were placed into each dish and randomly arranged around the outside perimeter of the dish. Within a given dish, the beetle had access to all foliage sections. The petri dishes were placed in clear plastic bags to prevent drying of the leaf discs and were held under a 16:8 photoperiod (L:D) at approximately $25^{\circ} \mathrm{C}\left(77^{\circ} \mathrm{F}\right)$. The dishes were examined daily for 7 days. The foliage discs were removed each day from the dishes, replaced, and visually examined for the percent of leaf tissue removed (nearest 10\%).

\section{Field Defoliation Study, 1997}

After all beetle feeding had ceased, a field defoliation survey was conducted for all Tilia species/hybrids evaluated in the no-choice and multiple-choice tests. 
Depending on availability, 3 to 5 single tree replicates for each Tilia genotype were visually rated for percent defoliation using the following scale: NF = no feeding, $\mathrm{VL}=$ very light feeding ( $1 \%$ to $10 \%), \mathrm{L}=$ light feeding ( $11 \%$ to $25 \%), M=$ moderate feeding ( $25 \%$ to $50 \%$ ), $\mathrm{H}=$ heavy feeding ( $>50 \%)$. Trees were growing at The Morton Arboretum and were 2 to $10 \mathrm{~m}(6.6$ to $10 \mathrm{ft})$ in height with diameters at breast height of 2.5 to $15 \mathrm{~cm}$ ( 1 to $6 \mathrm{in}$.). A field defoliation survey was not conducted in 1995 because beetle pressure was not high enough to detect differences.

\section{Statistical Analysis}

Measures of preference were subjected to analysis of variance (ANOVA) using species/hybrid as the main effect. Percent defoliation for each species/hybrid was arcsine square-root transformed before analysis to correct for normality. Means of significant effect were compared with a Student-Newman-Keuls multiple comparison test. All data are presented as means \pm SEM. Data were analyzed using SigmaStat for Windows (Jandel Scientific 1992).

\section{RESULTS AND DISCUSSION No-Choice Laboratory Feeding Study, 1995}

Significant differences were observed for mean percent leaf tissue consumed $(F=155.5$; $\mathrm{df}=15,159$; $P<0.0001)$ and mean dried fecal pellet weight $(F=$ 7.8; $\mathrm{df}=15,159 ; \mathrm{P}<0.0001$ ). Overall, T. platyphyllos, T. $\times$ euchlora, $T$. cordata (reference), T. orbicularis, $T$. mongolica, T. maximowicziana, and T. amurensis had significantly more leaf tissue removed as compared to the least-preferred species, T. americana (Table 1). Tilia tomentosa 'Erecta', T. tomentosa, T. heterophylla, T. caroliniana, T. petiolaris, T. oliveri, $T$. chinensis, and $T$. japonica were intermediate, with less than $18 \%$ of the leaf area consumed (Table 1 ). In a recent study, Potter et al. (1998) found that Crimean linden (T. × euchlora) and all 4 cultivars ('Olympic', 'Chancellor', 'Greenspire', and 'Glenleven') of littleleaf linden ( $T$. cordata) were severely damaged even during years with less beetle activity. By comparison, T. americana 'Legend', T. americana 'Redmond', and silver linden, T. tomentosa 'Sterling' were found by Potter et al. (1998) to have generally sustained less damage than littleleaf or Crimean lindens. Likewise, Sacksteder and Gerhold (1978) reported that I. cordata 'Greenspire' had significantly greater defoliation than $T$. tomentosa.
Table 1. Mean percent leaf area consumed and mean dried fecal pellet weights of adult Japanese beetles feeding on selected Tilia spp. and cultivars in a no-choice laboratory test (July 1995).

\begin{tabular}{|c|c|c|}
\hline Species/variety* & $\begin{array}{l}\text { Mean percent leaf } \\
\text { area consumed }\end{array}$ & $\begin{array}{l}\text { Mean dried fecal } \\
\text { pellet weight (mg) }\end{array}$ \\
\hline \multicolumn{3}{|l|}{ European species } \\
\hline T. tomentosa 'Erecta' & $15.69 \mathrm{ab}$ & $55.4 \mathrm{bc}$ \\
\hline T. platyphyllos & $45.09 c$ & $79.5 c$ \\
\hline T. $\times$ euchlora & $29.04 c$ & $60.9 \mathrm{bc}$ \\
\hline T. cordata (reference) & $23.23 \mathrm{~b}$ & $79.9 \mathrm{c}$ \\
\hline T. tomentosa & $17.34 \mathrm{ab}$ & $60.7 \mathrm{bc}$ \\
\hline \multicolumn{3}{|c|}{ North American species } \\
\hline T. americana & $6.34 a$ & $23.1 \mathrm{ab}$ \\
\hline T. heterophylla & $11.64 \mathrm{ab}$ & $58.5 \mathrm{bc}$ \\
\hline T. orbicularis & $29.15 c$ & $66.7 \mathrm{bc}$ \\
\hline T. caroliniana & $11.38 \mathrm{ab}$ & $47.9 \mathrm{bc}$ \\
\hline \multicolumn{3}{|l|}{ Asian species } \\
\hline T. petiolaris & $11.73 \mathrm{ab}$ & $38.2 \mathrm{ab}$ \\
\hline T. mongolica & $22.92 \mathrm{~b}$ & $71.3 \mathrm{c}$ \\
\hline T. maximowicziana & $18.33 \mathrm{~b}$ & $51.9 \mathrm{bc}$ \\
\hline T. oliveri & $9.79 \mathrm{ab}$ & $28.0 \mathrm{ab}$ \\
\hline T. chinensis & $17.83 \mathrm{ab}$ & $36.1 \mathrm{ab}$ \\
\hline T. amurensis & $28.00 \mathrm{c}$ & $76.9 \mathrm{c}$ \\
\hline T. japonica & $12.42 \mathrm{ab}$ & $17.9 \mathrm{a}$ \\
\hline
\end{tabular}

*Values within columns followed by the same letter are not signficantly different ( $P<0.05$; Student-Neuman-Keuls multiple comparison test).

Overall, mean dried fecal pellet weights reflected the rankings for the mean percentage of leaf area consumed, with species with a greater percentage of leaf area consumed having greater mean dried fecal pellet weights (Table 1). Tilia platyphyllos, T. cordata, T. mongolica, and T. amurensis had significantly greater dried fecal pellet weights ( 71 to $80 \mathrm{mg}$ ), while T. japonica, T. americana, T. petiolaris, T. oliveri, and $T$. chinensis had significantly lower mean dried fecal pellet weight (18 to $38 \mathrm{mg}$ ). The remaining genotypes were moderately preferred with mean dried fecal pellet weights between 48 and $66.7 \mathrm{mg}$ (Table 1).

\section{No-Choice Laboratory Feeding Study, 1997}

Overall, individual trees had no significant effect on mean percentage of leaf tissue consumed ( $F=13.4$; $\mathrm{df}=4,224 ; P=0.11$ ) or mean dried fecal pellet weight $(F=8.5 ; \mathrm{df}=4,224 ; P=0.08)$. Therefore, the data for all trees for each species/hybrid were pooled.

In contrast to 1995 , no significant difference $(F=$ 13.9; $\mathrm{df}=3,119 ; P=0.36$ ) was observed for mean percent leaf tissue consumed among the 3 Tilia genotypes and the standard (S. albidum) (Table 2) or 
Table 2. Mean percent leaf area consumed and mean dried fecal pellet weights for adult Japanese beetles feeding on selected Tilia spp. and cultivars growing in the Tilia spp. collection in a nochoice laboratory feeding study (July 1997).

\begin{tabular}{llll}
\hline Species/variety & $\begin{array}{l}\text { Mean percent leaf } \\
\text { area consumed }\end{array}$ & $\begin{array}{l}\text { Mean dried fecal } \\
\text { pellet weight }(\mathrm{mg})\end{array}$ & $\begin{array}{l}\text { Field defoliation' } \\
\text { survey rating }\end{array}$ \\
\hline T. amurensis & $44.8 \mathrm{a}$ & $68.1 \mathrm{~b}$ & $\mathrm{~L}$ \\
$\begin{array}{l}\text { T. tomentosa } \\
\text { T. heterophylla }\end{array}$ & $50.5 \mathrm{a}$ & $38.4 \mathrm{a}$ & $\mathrm{M}$ \\
$\begin{array}{r}\text { 'Continental Appeal' } \\
\text { Sassafras albidum }\end{array}$ & $49.0 \mathrm{a}$ & $44.3 \mathrm{ab}$ & $\mathrm{L}$ \\
(standard) & & $38.1 \mathrm{a}$ & \\
\hline
\end{tabular}

"Values within columns followed by the same letter are not significantly different $(P<0.05$;

Student-Neuman-Keuls multiple comparison test).

FField defoliation rating: $\mathrm{NF}=$ no feeding, $\mathrm{VL}=$ very light $(1-10 \%$ defoliation $), \mathrm{L}=$ light

$(11-25 \%), \mathrm{M}=$ moderate $(26-50 \%), \mathrm{H}=$ heavy $(>50 \%)$

for the 7 Tilia genotypes growing in the paper pots in the nursery $(F=12.8 ; \mathrm{df}=7,204 ; P=0.24)$ (Table 3). Mean percent leaf tissue consumed in both studies ranged from a low of $44 \%$ for T. cordata 'Prestige' to $62 \%$ for T. cordata 'Greenspire' (Table 2 and Table 3). In a direct comparison of like cultivars in our study and in a study by Potter et al. (1998), $T$. cordata 'Greenspire' had the highest degree of leaf tissue consumed (62\%). In addition, we found $T$. tomentosa 'Sterling' to have the second highest level of leaf tissue consumed (61\%), whereas Potter et al. (1998) found T. tomentosa 'Sterling' to have one of the lowest levels of feeding damage. Tilia tomentosa in our study had a lower amount of leaf tissue consumed, which is consistent with Potter et al. (1998). Tilia americana 'Redmond' in this study had lower feeding damage, which is also consistent with Potter et al. (1998) for this same cultivar.

Significant differences $(F=36.2 ; \mathrm{df}$ $=3,119 ; P<0.001)$ in mean dried fecal pellet weights were observed however, among the 3 Tilia genotypes and the standard (S. albidum) growing in the field (Table 2) and among the 7 genotypes growing in the paper pots $(F=31.5 ; \mathrm{df}=7,204 ; P=0.001)$ (Table 3). Tilia americana 'Redmond' had significantly greater dried fecal pellet weights of $68.0 \mathrm{mg}$. (Table 3). Sassafras albidum (standard) and $T$. tomentosa had significantly lower

Student-Neuman-Keuls multiple comparison test).

'Species identification unknown. mean dried fecal pellet weights of 38.1 and $38.4 \mathrm{mg}$, respectively (Table 2 ). The remaining Tilia genotypes were moderately preferred with pellet weights of 44.3 to $63.9 \mathrm{mg}$ (Table 2 and Table 3).

Mean dried fecal pellet weight for T. tomentosa was not as consistent between the 1995 and 1997 studies (Table 1 and Table 2).

\section{Multiple-Choice Laboratory Feeding Study, 1997}

Overall, results from the multiplechoice study tended to support the preference rankings observed in the no-choice laboratory bioassays and the field defoliation survey. Adult Japanese beetles fed significantly more ( $F=$ 24.2; $\mathrm{df}=5,240 ; P<0.001$ ) on T. tomentosa 'Sterling' as compared to the other 5 Tilia genotypes (Table 4). About $37 \%$ of the leaf tissue was removed from the $T$. tomentosa 'Sterling' leaf discs, while only $6 \%$ to $17 \%$ damage was recorded for the other 5 varieties. These results are consistent with the nochoice laboratory tests: T. tomentosa 'Sterling' was second only to T. cordata 'Greenspire' in preference, with $61 \%$ defoliation (Table 3). In the field defoliation survey, T. tomentosa 'Sterling' exhibited only

Table 3. Mean percent leaf area consumed and mean dried fecal pellet weights of adult Japanese beetles feeding on selected Tilia spp. and cultivars growing in $3.8-\mathrm{L}$ (10-gal) pots in a no-choice laboratory feeding study (July 1997).

\begin{tabular}{|c|c|c|c|}
\hline Species/variety ${ }^{2}$ & $\begin{array}{l}\text { Mean percent leaf } \\
\text { area consumed }\end{array}$ & $\begin{array}{l}\text { Mean dried fecal } \\
\text { pellet weight (mg) }\end{array}$ & $\begin{array}{l}\text { Field defoliation } \\
\text { survey rating }\end{array}$ \\
\hline \multicolumn{4}{|l|}{ European species } \\
\hline T. cordata 'Prestige' & $44.4 \mathrm{a}$ & $60.4 \mathrm{ab}$ & M \\
\hline T. cordata 'Fairview' & $55.6 \mathrm{a}$ & $58.9 \mathrm{ab}$ & L \\
\hline T. cordata 'Greenspire' & $61.7 \mathrm{a}$ & $44.6 \mathrm{ab}$ & M \\
\hline T. platyphyllos 'Parade' & $46.0 \mathrm{a}$ & $55.2 \mathrm{ab}$ & NF \\
\hline T. tomentosa 'Sterling' & $61.0 \mathrm{a}$ & $63.9 \mathrm{ab}$ & $\mathrm{L}$ \\
\hline \multicolumn{4}{|c|}{ North American species } \\
\hline T. americana 'Redmond' & $50.8 \mathrm{a}$ & $68.0 \mathrm{~b}$ & $\mathrm{M}$ \\
\hline 'Sundance'x & $41.0 \mathrm{a}$ & $56.7 \mathrm{ab}$ & VL \\
\hline $\begin{array}{l}\text { Sassafras albidum } \\
\text { (standard) }\end{array}$ & $49.8 \mathrm{a}$ & $38.1 \mathrm{a}$ & \\
\hline
\end{tabular}

${ }^{2}$ Values within columns followed by the same letter are not significantly different $(P<0.05$;

Field defoliation rating: $\mathrm{NF}=$ no feeding, $\mathrm{VL}=$ very light $(1-10 \%$ defoliation $), \mathrm{L}=$ light

$(11-25 \%), \mathrm{M}=$ moderate $(26-50 \%), \mathrm{H}=$ heavy $(>50 \%)$. 
Table 4. Mean percent leaf tissue consumed by Japanese beetles for multiple-choice studies on selected Tilia spp. and varieties in a multiplechoice test (August 1997).

\begin{tabular}{lc}
\hline & Percent leaf tissue consumed, \\
Species/variety & multiple-choice test \\
\hline T. amurensis & $6.4 \mathrm{a}$ \\
T. platyphyllos 'Parade' & $17.1 \mathrm{a}$ \\
T. cordata 'Prestige' & $3.0 \mathrm{a}$ \\
'Sundance'y & $14.8 \mathrm{a}$ \\
T. tomentosa & $7.0 \mathrm{a}$ \\
T. tomentosa 'Sterling' & $36.8 \mathrm{~b}$ \\
\hline
\end{tabular}

vValues within a column followed by the same letter are not significantly different $(P<0.05 ;$ Student-Neuman-Keuls multiple comparison test).

YSpecies identification unknown.

light (L) feeding damage (Table 3). The more mature T. tomentosa trees experienced a moderate (M) feeding rating (Table 2 ) but only $3 \%$ defoliation in the multiple-choice bioassay test (Table 4). The less-preferred genotype of T. cordata 'Prestige' exhibited light to moderate (M) feeding damage in the field and had approximately $44 \%$ damage in the laboratory bioassays (Table 3). Personal observations by the authors have revealed that Tilia platyphyllos 'Parade', $T$. cordata 'Prestige', 'Sundance', and T. tomentosa have dense mats of white tomentose and/or very long fine hairs on the lower leaf surface. In contrast, the more highly preferred T. tomentosa 'Sterling' has sparse, short stellate (star-shaped) hairs on the lower leaf surface. The differences in pubescence may partially account for the differences in preference observed in the multiple-choice study.

\section{Field Defoliation Survey, 1997}

Overall, rankings for the field defoliation survey were fairly consistent with the no-choice and multiple-choice laboratory feeding studies. Tilia genotypes, such as $T$. cordata 'Greenspire', T. tomentosa, $T$. tomentosa 'Sterling', and T. cordata 'Fairview', had light (L) to moderate (M) feeding damage and tended to have higher percentages of leaf area consumed in the no-choice laboratory feeding study. One exception, T. cordata 'Prestige', had moderate feeding in the field but had a lower percentage of leaf area consumed (Table 3). Fleming (1972) classifies
T. cordata as having moderate feeding and $T$. tomentosa as general light feeding. Genotypes such as T. amurensis, T. platyphyllos 'Parade', 'Sundance', and T. tomentosa, which had no (NF) to light (L) feeding, also had lower percentages of leaf area consumed both in the no-choice and multiple-choice laboratory feeding studies (Tables 2 through 4).

Leaf pubescence may play a role in feeding preference of Tilia spp. by adult Japanese beetles. We have observed that the upper leaf surfaces of the Tilia spp. evaluated in the 1997 study were glabrous, while the lower leaf surfaces varied in presence and density of hairs. Tilia genotypes that are glabrous or have very sparse densities of hairs, such as $T$. cordata 'Fairview', T. cordata 'Greenspire', and T. tomentosa 'Sterling', tend to have more leaf area consumed as compared to $T$. cordata 'Prestige', $T$. platyphyllos 'Parade', and T. tomentosa, which have thick white tomentose mats and/or long and upright hairs. The one exception is T. americana 'Redmond', which has a glabrous lower leaf surface but which experienced feeding damage comparable to the highly pubescent genotypes. We have also observed in related feedingpreference studies that elm (Ulmus spp.) genotypes with heavy pubescence (i.e., U. lamellosa, U. macrocarpa) tend to be less preferred by adult Japanese beetles (unpublished data). Undoubtedly, other factors-such as leaf surface chemicals, internal chemicals, or leaf tissue toughness-may also be involved in apparent resistance.

\section{CONCLUSION}

Using mean percent leaf area consumed and mean dried fecal pellet weights as measures of susceptibility, the Asian species of $T$. petiolaris, T. oliveri, $T$. chinensis, and $T$. japonica show promise for partial resistance to Japanese beetles. Three North American species, T. americana, T. heterophylla, and T. caroliniana also show promise along with the pubescent European species of T. tomentosa and T. tomentosa 'Erecta'. Further studies are needed to determine the factor(s) responsible for apparent resistance and the horticultural qualities of these species for use in the landscape and as street trees. 


\section{LITERATURE CITED}

Fleming, W.E. 1972. Biology of the Japanese beetle. U.S. Dept. Agric. Tech. Bull. 1449.

Hawley, I.M., and F.W. Metzger. 1940. Feeding habits of the adult Japanese beetle. U.S. Dept. Agric. Circ. 547.

Jandel Scientific. 1992. SigmaStat for Windows. San Rafael, CA.

Ladd, T.L., Jr. 1987. Japanese beetle (Coleoptera: Scarabaeidae): Influence of favored food plants on feeding response. J. Econ. Entomol. 80:1014-1017.

Ladd, T.L., Jr. 1989. Japanese beetle (Coleoptera: Scarabaeidae): Feeding by adults on minor host and nonhost plants. J. Econ. Entomol. 82:1616-1619.

Miller, F, and G. Ware, 1999. Adult Japanese beetle (Coleoptera: Scarabaeidae) feeding preference for Asian elm species and hybrids. J. Econ. Entomol. (In press.)

Potter, D.A., P.G. Spicer, D. Held, and R.E. McNiel. 1998. Relative susceptibility of cultivars of flowering crabapples, lindens, and roses to defoliation by Japanese beetles. J. Environ. Hortic. 16(2): 105-110.

Ranney, T.G., and J.F. Walgenbach. 1992. Feeding preference of Japanese beetles for taxa of birch, cherry and crabapple. J. Environ. Hortic. 10:177-180.

Raupp, M.J., C.S. Koehler, and J.A. Davidson. 1992. Advances in implementing integrated pest management for woody landscape plants. Annu. Rev. Entomol. 37:561-586.

Sacksteder, C.J., and H.D. Gerhold. 1978. Japanese beetle preferences among linden cultivars. Proc. Metropolitan Tree Improvement Alliance (METRIA) 1:44-48.

Spicer, P.G., D.A. Potter, and R.E. McNiel. 1995. Resistance of flowering crabapple cultivars to defoliation by the Japanese beetle (Coleoptera: Scarabaeidae). J. Econ. Entomol. 88(4):979-985.
Acknowledgements. The authors wish to thank D. Potter, University of Kentucky, for his helpful review of an earlier draft of this manuscript. Special thanks is extended to D. Danielson, The Morton Arboretum, for her assistance in field collection of beetles and laboratory work, and T. Tiddens, the Chicago Botanic Garden, for supplying us with Japanese beetles. Thanks and appreciation is due to M. Miller for her assistance with data entry and manuscript preparation.

${ }^{1 *}$ Countryside Extension Center

University of Illinois

6438 Joliet Road

Countryside, IL 60525

${ }^{2}$ The Morton Arboretum

4100 Illinois Route 53

Lisle, IL 60532

*Corresponding author 
Résumé. Divers espèces et hybrides de Tilia sont utilisés fréquemment comme arbres de rues et dans les espaces verts. Planter des espèces de tilleuls qui sont moins attirantes pour le scolyte japonais (Popillia japonica Newman) pourrait minimiser grandement les besoins en vaporisations d'insecticides, ce qui en retour diminuerait la contamination environnementale, les risques pour l'exposition humaine et les coûts de gestion. En conséquence, une étude a été mise sur pied pour évaluer les espèces horticoles désirables de Tilia spp. par rapport aux préférences d'alimentation du scolyte japonais adulte. Un objectif secondaire était de déterminer si la pubescence sur les feuilles constituait un facteur de préférence alimentaire.
Resumen. Especies e hibridos de Tilia son ampliamente usados en paisajes urbanos y como árboles en las calles. Las plantaciones de Tillia que son menos preferidas por el escarabajo Japonés (Popillia japonica Newman) minimizarían la necesidad de aspersión de insecticidas, lo cual reduciria la contaminación ambiental, la exposición humana, y los costos de mantenimiento. Por consiguiente, se inició un estudio para evaluar las especies de Tilia, hortícolamente deseables, en cuanto a las preferencias alimenticias por el escarabajo Japonés adulto. Un objetivo secundario fue determinar si la pubescencia de la hoja es un factor en la preferencia alimenticia. 